\title{
Pengembangan Model Pembelajaran Atletik Nomor Lempar untuk Anak Tunagrahita Ringan
}

\author{
Luthfie Lufthansa \\ IKIP Budi Utomo Malang. J1 Simpang Arjuno No.14B, Kauman, Kota Malang, 65119, Indonesia \\ Email: luthfielufthansa@ rocketmail.com \\ Received: 31January 2017; Revised:8 March 2017; Accepted: 28 April 2017
}

\section{Retracted}

Following a rigorous and careful concerns and consideration in the review of the article published in Jurnal Keolahragaan entitled "Pengembangan model pembelajaran atletik nomor lempar untuk anak tunagrahita ringan" Vol 5, No 1, pp. 39-49, April 2017, DOI: http://dx.doi.org/10.21831/jk.v5i1.12803

This paper has been found to violate the principles of Jurnal Keolahragaan Publication and has been retracted.

The article has contained redundant material and throughout a careful examination, the editor has found that the paper has also been published in Jurnal Pendidikan Jasmani Indonesia, Vol. 12, No. 2, pp. 5966, 2016, DOI: http://dx.doi.org/10.21831/jpji.v12i2.17103

The document and its content have been removed from Jurnal Keolahragaan, and reasonable effort should be made to remove all references to this article.

Permalink/DOI: http://dx.doi.org/10.21831/jk.v5i1.12803 